\title{
SHOULD CORPORATE SOCIAL RESPONSIBILITY AROUND THE WORLD BE MANDATORY OR VOLUNTARY?
}

\begin{abstract}
Corporate social responsibility (CSR) is an idea that has grown during the last three decades from the voluntary activity of business firms into a debate about whether CSR should be mandated by law because of the increased demand from society. Further, it has been argued that business corporations are owned by their shareholders, and the managers must concentrate on maximizing the wealth of their shareholders and not of the community. To determine how better to apply CSR, this paper begins with looking at the evolution of CSR as a system around the world and then discusses the definition of CSR. In addition, this paper explores the advantages and disadvantages of implementing voluntary CSR and then explores mandatory CSR. Moreover, in this paper, it is found that determining the proper CSR system depends on many factors in each country, such as the social, economic and legal factors that should be examined before applying mandatory or voluntary CSR.
\end{abstract}

\section{Keywords}

corporate social responsibility - voluntary application - mandatory application - corporate law - hard law - soft law

* Dr Mohammad Alwasmi, Assistant Professor in the School of Law in Kuwait University, Kuwait, https://orcid.org/0000-0001-7340-643X; e-mail: mohd.alwasmi@gmail.com.

** Dr Ahmad Alderbas, Assistant Professor in Gulf University for Science and Technology, Kuwait, https://orcid.org /0000-0002-6031-4074; e-mail: a.alderbas@gmail.com. 


\section{INTRODUCTION}

Corporate social responsibility (CSR) is an idea that has grown during the last three decades from the voluntary activity of business firms into a debate about whether CSR should be mandated by law because of the increasing demand from society. ${ }^{1}$

In simple terms, the laws and regulations of CSR aim to have corporations concentrate on benefiting organizations other than just their shareholders. In a more elaborate context, CSR regulations aim to ensure that corporations will avoid doing harm to the environment and will offer more protection to their employees and workers. Thus, it has been suggested that business corporations should be encouraged to act responsibly towards their communities even when there are no official legal obligations, and this is the objective of implementing CSR.

However, CSR as a concept is still not supported consensually by everyone, and thus, there are many opinions against it. The vagueness of the notion itself and the non-existence of a unified definition of CSR is a major reason why these opponents are not motivated to regulate CSR within a binding legal framework. ${ }^{2}$ Furthermore, the debate over whether CSR should be mandatory or voluntary starts with the fact that there are no unified worldwide regulations for CSR.

Thus, a voluntary code of CSR could be seen as better than legally mandated provisions from the view that a voluntary code is flexible and can provide for best practices far from bureaucracy, ${ }^{3}$ whereas, CSR as a hard law should not prevent or harden the corporation from achieving its main goals and responsibilities, as it has been claimed that CSR laws

${ }^{1}$ K. Japhet, V. K. Tawiah, M. Benjamin, “Debate on Mandatory Corporate Social Responsibility," SSRN Electronic Journal, 2015, p. 1, doi: 10.2139/ssrn.2592880 [last accessed 12.5.2020].

2 J. You, Legal Perspectives on Corporate Social Responsibility: Lessons from the United States and Korea, Springer, 2015, p. 27.

${ }^{3}$ C. Villiers, “Corporate Law, Corporate Power and Corporate Social Responsibility", in N. Boeger, R. Murray, Ch. Villiers (eds.), Perspectives on Corporate Social Responsibility: Corporations, Globalization and the Law, Cheltenham: Edward Elgar, 2008, p. 98. 
will prevent corporations from achieving their traditional and main objective, which is the maximization of shareholder wealth. ${ }^{4}$

Therefore, it is very important to analyse whether or not corporate social responsibility (CSR) should be mandatory to achieve the objectives expected from it. In other words, is there a demand for intervention from legislatures to enact laws and regulations when there is a lack of effort from corporations towards community participation through implementation of CSR?

Moreover, it has been suggested that the regulation of corporate social responsibility (CSR) differs from one country's legal system to another since such regulations must be compatible with multiple factors, such as the social, economic, and legal environments of each country. ${ }^{5}$ Accordingly, when it comes to drafting CSR regulations or laws, policymakers should take many factors into account, such as the social and economic conditions of the country, and not simply adopt another country's model of CSR. ${ }^{6}$ This paper's main purpose is to investigate whether laws should regulate CSR clearly, or whether CSR should be voluntary. To achieve the proper results, this paper starts with exploring the evolution of corporate social responsibility and explores its definition around the world. Furthermore, a discussion of voluntary CSR is included in one section, and a discussion of mandatory CSR is included in another.

\section{The Evolution Of Corporate Social Responsibility (CSR)}

Corporate social responsibility (CSR) is a notion that has gone through developments during the past decades from the voluntary activities of

${ }^{4}$ C. Parker, "Meta-Regulation: Legal Accountability for Corporate Social Responsibility", in D. McBarnet, A. Voiculescu, T. Campbell (eds.), The New Corporate Accountability: Corporate Social Responsibility and the Law, Cambridge: Cambridge University Press, 2007, pp. 207-37.

5 T. Clarke, International Corporate Governance a Comparative Approach, London: Routledge Taylor \& Francis Group, 2007, p. 270.

6 A. Settles, O. Melitonyan, J. Gillies, "CSR in Russia”, in Ch. Mallin (ed.), Corporate Social Responsibility: A Case Study Approach, Cheltenham: Edward Elgar, 2009, p. 83. 
business firms into a debate about whether CSR should be mandated by law because of the increasing societal demand or not. ${ }^{7}$

CSR proponents argue that corporations that affect society detrimentally, such as industrial corporations that cause pollution, for example, have a responsibility to contribute some of their profits to compensate people who are affected, but in the form of CSR obligations instead of charitable activities. ${ }^{8}$ Also, it has been argued that CSR is a notion that includes many elements relating to the responsibilities of businesses to society, and this understanding is derived from the belief that firms should replace the government's role in providing essentials for society and its citizens. ${ }^{9}$ Carroll in 2006 noted that "it appears that the corporate social responsibility concept has a bright future because, at its core, it addresses and captures the most important concerns of the public regarding business and society relationships."10

In contrast, Dine supported the school of thoughts that sees CSR as a nebulous concept when he stated that CSR stands on "vague principles and shaky foundation"; in addition, he said that:

the vagueness and breadth of the formulations at international, region$\mathrm{al}$ and national levels gives some credence to the claim that there is only a hollow presumption of agreement and that CSR is a concept which has no real definition.... There are not persistent squabbles as to what is meant by corporate social responsibility but also its basis and its relationship to that equally nebulous term corporate governance. ${ }^{11}$

${ }^{7}$ Japhet, Tawiah, Benjamin ", supra note 1, p. 3.

${ }^{8}$ Ibid.

${ }_{9}$ D. Jamali, W. Safadi, "Adaptations of CSR in the Context of Globalization. The case of the GCC", in G.Y. Wang (ed.), Globalization, IntechOpen, 2019, p. 124, doi: 10.5772/intechopen.79035 [last accessed 13.6.2020].

10 A. Carroll, "Corporate Social Responsibility: A Historical Perspective," in M. J. Epstein, K. O. Hanson (eds.), The Accountable Corporation, Westport, CA: Praeger Publishers, 2006, pp. 3-28.

11 J. Dine, K. Shields, “Corporate Social Responsibility: Do Corporations Have a Responsibility to Trade Fairly? Can the Fairtrade Movement Deliver the Duty?", in N. Boeger, R. Murray, C. Villiers (eds.), Perspectives on Corporate Social Responsibility: Corporations, Globalization and the Law, Cheltenham: Edward Elgar, 2008, p. 147. Also see J. Zhao, „Promoting More Socially Responsibly Corporations Through A Corporate Law Regulatory Framework", Legal Studies, 2017, Vol. 37 (1), p. 107, doi:10.1111/lest.12140. 
In the same vein, Milton Friedman suggests that a company's sole objective is to maximize shareholder profit; however, it is the government's obligation to take responsibility for society since corporations pay taxes to the government, and therefore, the government should provide for the welfare of society. ${ }^{12}$ Further, the opponents of CSR claim that regulations infringe the power of corporate managers, thus forcing them to depart from achieving the main goal of the corporation, which is to maximize shareholder profits, and instead spend the corporation's budget on CSR activities. ${ }^{13}$

The opponents of CSR rely heavily on the fact, however, that CSR have been through considerable developments, and the definition of CSR is not yet unified whether nationally or internationally. ${ }^{14}$ It has been alleged that CSR was explored by Carroll in 1979 when he said of CSR that "the social responsibility of business encompasses the economic, legal, ethical, and discretionary expectations that society has of organizations at a given point in time."15 Further, in regard to the non- uniform definition of CSR, it has been said that "while there is no single, commonly accepted definition of corporate social responsibility, or CSR, it generally refers to business decision-making linked to ethical values, compliance with legal requirements, and respect for people, communities, and the environment."16

Furthermore, CSR's definition varies based on the definer's perspective; for example, if it has been defined from a legal perspective, as Professor Merrick Dodd has suggested, then it is a legal responsi-

12 M. Friedman, "The Social Responsibility of Business is to Increase its Profits," New York Times, 13.9.1962, p. 126, http://www.charity.org/site/c.gtJUJFMQIqE/b.3416753, mentioned in Japhet, Tawiah, Benjamin, supra note 1.

${ }^{13}$ L. Becchetti, R. Ciciretti, P. Conzo, "The Legal Origins of Corporate Social Responsibility", CEIS Research Paper, 2013, No. 291, p. 5.

${ }^{14}$ J. Zhao, "Regulation Of Corporate Social Responsibility Through the Lens of Board Accountability and The Case of China", in J. Plessis, U. Varottil, J. Veldman (eds.), Globalization Of Corporate Social Responsibility And Its Impact On Corporate Governance, Switzerland: Springer International Publishing AG, 2018, p. 124.

15 A. Carroll, "A Three-Dimensional Conceptual Model of Corporate Social Responsibility Performance," Academy of Management Review, 1979, Vol. 4, pp. 479-505.

${ }^{16}$ M. A. Camilleri, Corporate Sustainability, Social Responsibility and Environmental Management. An Introduction to Theory and Practice with Cases Studies, Springer International Publishing, 2017, p. 5. 
bility wherein managers, as trustees of a corporation, are obligated to their beneficiaries: stockholders, employees, customers, and the general public. ${ }^{17}$

Additionally, some definitions of CSR have clearly stated that CSR may be indicated by "companies voluntarily going beyond what the law requires to achieve social and environmental objectives during the course of their daily business activities." ${ }^{\prime 18}$ This can be understood as the acceptance of CSR as a voluntary system.

Likewise, CSR has been defined with emphasis on voluntary performance as: "A concept whereby companies integrated social and environmental concerns in their business operations and their interaction with their stakeholders on a voluntary basis". ${ }^{19}$

Cadbury in 2002 defined CSR in the UK as "the broadest way of defining social responsibility is to say that the continued existence of companies is based on an implied agreement between business and society" and that "the essence of the contract between society and business is that companies shall not pursue their immediate profit objectives at the expense of the longer-term interests of the community". ${ }^{20}$

International organizations have their own definitions for CSR, as The World Business Council for Sustainable Development defined it as "the commitment of businesses to contribute to sustainable economic development by working with their employees, their families, the local community, and society at large to improve their lives in ways which are good for business and for development". ${ }^{21}$ The World Bank Group in 2002 gave a definition of CSR with its statement that

17 D. Merrick, "For whom are Corporate Managers Trustees?" Harvard Law Review, 1932, Vol. 45, pp. 1145-54, mentioned in L. Wedderburn, "Southey Memorial Lecture 1984: The Social Responsibilities of Companies," Melbourne University Law Review, 1985, Vol. 4, p. 15.

18 European Commission, “Corporate Social Responsibility (CSR) in the EU”, http:// ec.europa.eu/social/main.jsp?catId=331.?, p. 3 [last accessed 2.7.2020].

${ }^{19}$ Clarke, supra note 5, p. 279.

20 A. Cadbury, Corporate Governance and Chairmanship: A Personal View, Oxford: Oxford University Press, 2002, mentioned in C. Mallin (ed.), Corporate Social Responsibility: A Case Study Approach, Cheltenham: Edward Elgar Publishing, 2009, p. 83.

${ }^{21}$ The Definition of the World Business Council for Sustainable Development 2002. 
CSR is at heart a process of managing the costs and benefits of business activity to both internal (for example workers, shareholders, investors) and external (institutions of public governance, community members, civil society groups, other enterprises) stakeholders. Setting the boundaries for how the costs and benefits are managed is partly a question of business policy and strategy and partly a question of public governance. ${ }^{22}$

Accordingly, it transpires that each country should have its own definition of CSR that is decided after examining the availability of the factors that should be related to the application of CSR. In other words, the CSR concept might differ not only from one country to another, but also from one definer to another; for instance, the government definition of CSR will not be the same as that of a private corporation. ${ }^{23}$

Moreover, defining CSR is not the only element that ensures its sound application, the way that CSR is applied is also a highly important factor, and it is clear that whether the application of CSR is mandatory or voluntary has a major effect.

\section{CSR REGULATIONS}

There are no unified regulations for CSR that fit all countries, and to ensure an appropriate implementation of CSR, its regulations must be adopted carefully, as they should be well suited to many factors in the country, and it has been said that the law is a major player in determining a framework of corporate management and accountability. ${ }^{24}$

Corporations are encouraged to act responsibly towards the community, although there are no official legal obligations. Additionally, there are opinions that many corporations are not committed to their supposed role in the community; thus, it is better to make such corporations obliged by a legal instrument to behave responsibly towards society. This approach has been supported by the following:

${ }^{22}$ World Bank Group, Public Sector Roles in Strengthening Corporate Social Responsibility: a Baseline Study, Washington, DC: World Bank Group, 2002.

${ }^{23}$ Jamali and Safadi, supra note 9, p. 124.

${ }^{24}$ Clarke, supra note 5, p. 279. 
CSR is best understood as a niche rather than a generic strategy: it makes sense for some firms in some areas under some circumstances. Many of the proponents of corporate social responsibility mistakenly assume that because some companies are behaving more responsibly in some areas, some firms can be expected to behave more responsibly in more areas. This assumption is misinformed. There is a place in the market economy for responsible firms. But there is also a large place for their less responsible competitors... precisely because CSR is voluntary and market-driven, companies will engage in CSR only to the extent that it makes business sense for them to do. Civil regulation has proven capable of forcing some companies to internalize some of the negative externalities associated with some of their economic activities. But CSR can reduce only some market failures. ${ }^{25}$

In this vein, it has been suggested that Dodd argued that corporate managers have fiduciary duties, not only to their shareholders, but also to any member of society who is affected by such managerial decisions. This suggestion was opposed by Professor Berle, who invented the notion of shareholder supremacy and denied CSR as a notion. ${ }^{26}$ However, in the end, Berle stated his acknowledgement of the opinion of Dodd:

Twenty years ago, the writer had a controversy with the late Professor E. Merrick Dodd of the Harvard Law School, the writer holding that corporate powers were powers in trust for shareholders, while Professor Dodd argued that these powers were held in trust for the entire community. The argument has been settled...squarely in favour of Professor Dodd's contention. ${ }^{27}$

Also, It could be said that laws mandating CSR mean that corporations will be concentrating on benefiting organizations other than their shareholders. In a more elaborate context, CSR regulations will ensure that corporations will avoid doing harm to the environment and will offer more protection to their employees and other workers.

${ }^{25}$ Ibid., p. 270.

${ }^{26}$ Ibid., p. 38.

27 A. Berle, The 20th Century Capitalist Revolution, New York: Harcourt, Brace \& World, 1954, p. 169. 
However, Stakeholder theory is considered a major support to implementing voluntary CSR, as it encourages corporate managers not only to donate to charitable entities but also to go further and consider the corporation's other constituencies in addition to shareholders, such as employees, creditors, and society as a whole. ${ }^{28}$

Furthermore, in terms of the voluntary application of CSR by corporations, it has been found that such corporations gain financial profits from consumer satisfaction, but it should be mentioned here that the benefits are not identical for all companies. ${ }^{29}$ Interestingly, if the corporation which is applying the CSR voluntarily could lead in that, the government would award it more privileges than other corporations receive. $^{30}$

Accordingly, it is a fact that (CSR) regulations differ from the legal system of one country to another since such regulations must be compatible with multiple factors, such as the social, economic, and legal environments in each country. ${ }^{31}$ In this regard, to draft CSR regulations or law, policymakers should take many aspects into account, such as the social and economic conditions of their country, and not adopt any other country's model of CSR. ${ }^{32}$

In elaborating on the enactment of CSR regulation, it has been found that some countries might not need to apply all the CSR guidelines in their country based on the existence of the infrastructure for CSR, whereas many countries suffer from some weaknesses regarding application of CSR, for example: ${ }^{33}$

- An absence of credible monitoring and verification processes for CSR initiatives:

- A lack of governmental involvement and/or investment in international CSR initiatives, which contributes significantly to their underperformance:

${ }_{28}$ You, supra note 2, p. 58.

29 B. Coyle, Corporate Governance Essentials, London: ICSA Publishing, 2008, p. 241.

${ }^{30}$ J. Zhao, J.P. Tribe, "Corporate Social Responsibility in an Insolvent Environment: Directors' Continuing Obligations in English Law," International Company and Commercial Law Review, 2010, Vol. 21, p. 318-9.

31 Clarke, supra note 5, p. 23

32 Settles, Melitonyan, Gillies, supra note 6, p. 81.

${ }^{33}$ According to a survey conducted by the Royal Institute for International Affairs and Civil Society Groups mentioned in Clarke, supra note 5, p. 271. 
- An excessive focus on getting businesses to make commitments to CSR and not enough focus on enabling them to implement them effectively.

- A lack of engagement with the governments of developing countries and their sustainable development priorities (e.g., economic development and poverty reduction).

Furthermore, it has been found that CSR components are not similar in every country but in general revolve around it or should encompass it: ${ }^{34}$

- Minimising damage to the environment and promoting sustainable business development, i.e., business growth that does not have adverse long-term consequences for the environment and the Earth's resources;

- Having liberal employment policies;

- Investing money in local communities;

- Helping in the fight against crime.

It could be submitted that regulating CSR to be voluntary or legally binding entails first assessing the business and legal culture; for instance, Dodd commented on corporate responsibility, in 1932 during the Great Depression in the United States, in the Harvard Law Review: "There is in fact a growing feeling, not only that business has responsibilities to the community, but that our corporate managers who control business should voluntarily and without waiting for legal compulsion manage it in such a way as to fulfil these responsibilities." ${ }^{35}$ This passage suggests that corporate managers should manage their companies' responsibilities to the community before those responsibilities must be provided by law. But it has been argued that voluntary implementation of CSR has come to an end as the legal mechanism to apply CSR has emerged. ${ }^{36}$ In general, CSR is usually implemented through voluntary codes in business corporations, but some jurisdictions have provided for mandatory CSR regulation in their corporate laws such as China, India and Indonesia.

${ }^{34}$ Coyle, supra note 29, p. 23.

35 E. Dodd, "For Whom Are Corporate Managers Trustees?", Harvard Law Review, 1932, Vol. 45(7), pp. 1145-1163, doi:10.2307/1331697.

${ }^{36}$ D. McBarnet, "Corporate Social Responsibility Beyond Law, through Law, for Law”, University of Edinburgh School of Law Working Paper, 2009, No. 3, pp. 29-30. 
Accordingly, the voluntary and mandatory application of CSR will be discussed in the following sections.

\section{Voluntary Application Of Corporate Social RESPONSIBILITY}

The voluntary code of CSR could be viewed as better than mandated provisions by law from the standpoint that a voluntary code is flexible and can provide for best practices far removed from bureaucracy; on the other hand ${ }^{37}$ the law is an insufficient tool to control the behaviour of corporate managers in regard to applying CSR in their corporations. ${ }^{38}$

Moreover, it is a fact that many countries around the world provide voluntary CSR systems and can provide corporate managements with the right to decide the appropriate percentage of their profits to be devoted to CSR activities based on their strategic plans, Furthermore, in the voluntary CSR system, corporations try to attract customers by enhancing their corporate image through more spending on social activities and by enhancing community welfare. ${ }^{39}$ However, it could be submitted that such a pattern to implement CSR must be supervised by governments to ensure the adequate application of minimum standards of CSR. But local governments have not been eager to provide for CSR in their laws, and instead, they prefer that such regulations are implemented by soft laws within international categories such as the guidelines of the OECD and UNGP. ${ }^{40}$

37 Villiers, supra note 3, p. 99.

${ }^{38}$ C. Scott, "Reflexive Governance, Meta-Regulation and Corporate Social Responsibility: The Heineken Effect". in Perspectives on Corporate Social Responsibility: Corporations, Globalization and the Law, N. Boeger, R. Murray, C. Villiers (eds.), Cheltenham: Edward Elgar Publishing, 2008, pp.174-5.

39 Zhao, supra note 11, p. 111. See also C. Bocean, C. Sitnikov, "ISO 26000: Is it a Case of Implementation or Simple Reporting? An Exploration of CSR Standards in Companies in Romania", in S. Idowu, C. Stinikov, L. Moratis (eds.), ISO 26000 - A Standardized View on Corporate Social Responsibility, Practice, Cases and Controversies, Springer International Publishing, 2019, p. 65.

${ }^{40}$ These two organizations guidelines provide for CSR aspects that the corporations should observe, see L. Backer, “Corporate Social Responsibility in Weak Governance Zones", Santa Clara Journal of International Law, 2016, Vol. 14, p. 297. 
The United States of America is one of the developed countries: CSR is not mandated in the legal system in the US, but corporate law has given corporate managers an opportunity to be committed to society as a whole when they make their managerial decisions. In other words, US corporate law provides significant discretion for managers to implement CSR without any legal obligation to do so.

In line with this situation, it has been found that the US courts, in their decisions, have actively encouraged the corporate decisions that managers have made in favour of the whole of society and not just their shareholders. ${ }^{41}$

In the legal case of Dodge v. Ford Motor Co., the corporation's voluntary duty to the community was discussed, as the Dodge brothers were minority shareholders who sued Henry Ford, the major shareholder, for not distributing dividends despite the remarkable profits that had been made. $^{42}$

Henry Ford expressly announced that the decision to retain profits was so that they could be invested to expand the corporation's operations to benefit the community, as Ford planned to expand the production of cars and thereby reduce prices to enable more Americans to buy cars and to increase the number of jobs for the members of society.

The court in this case forced the corporation to distribute the dividends because the corporation's directors must not deviate from the corporation's legal objective, which is to distribute profits to shareholders as provided for by corporate law, and the directors would be in breach of their duties if they pursued any other objectives. In the same case, it has been found that the court forced the corporation to distribute dividends because of the huge profits earned that year, which thus did not prevent Henry Ford from pursuing the expansion plan. ${ }^{43}$

Furthermore, the CSR debate in the US has interestingly appeared in the case of corporate takeovers, with the question being whether corporate directors should apply only the Revlon Doctrine, which means

${ }^{41}$ You, supra note 2, pp. 65-6, for example New Jersey Supreme Court ruling in A.P. Smith Mfg. Co. v. Barlow 98 A.2d 581 (N.J. 1953) which permit the business corporation to make charitable donations.

${ }^{42}$ Dodge v. Ford Motor Co., 170 N.W. 668 (Michigan 1919).

${ }^{43}$ F. Gevurtz, "Using Comparative and Transitional Corporate Law to Teach Corporate Social Responsibility, Global Business and Development Law Journal, 2011, Vol. 24, p. 42. 
they are obliged only to maximize shareholder profit from such takeover transactions, or should other constituencies in society also be considered.

In the case of Unocal Corp. v. Mesa Petroleum Co., the Delaware Supreme Court supported the principle that corporate directors should consider the interests of other constituencies of the corporation in addition to those of shareholders. ${ }^{44}$ Moreover, in the US, corporate constituency statutes have been legislated against takeover instruments to provide corporate directors with the authority to consider constituent interests before making any decision. ${ }^{45}$ For instance, in the state of Minnesota, the constituency statutes stipulate the following:

In discharging the duties of the position of director, a director may, in considering the best interests of the corporation, consider the interests of the corporation's employees, customers, suppliers, and creditors, the economy of the state and nation, community and societal considerations, and the long-term as well as short-term interests of the corporation and its shareholders including the possibility that these interests may be best served by the continued independence of the corporations. ${ }^{46}$

Therefore, it has been submitted that the voluntary nature of CSR regulation does not provide sufficient protection to the corporation's constituencies. ${ }^{47}$

Accordingly, in the US, corporate law does not prevent corporate managers from making decisions that favour stakeholders, but the firms and policymakers are still not confident about legislating CSR through a binding instrument. ${ }^{48}$ In other words, in the aforementioned discussion

44 Unocal Corp. v. Mesa Petroleum Co., 493 A.2d 946 (Del. 1985), mentioned in You, supra note 2, p. 71.

${ }^{45}$ Ibid., p. 72.

${ }^{46}$ Ibid., p. 73.

${ }^{47}$ Ibid., p. 75.

${ }^{48}$ Ibid., p. 41. For more elaboration regarding CSR debate in the US see, inter alia, L. Johnson, "Corporate Law and the History of Corporate Social Responsibility", in H. Wells (ed.), Research Handbook on the History of Company and Corporate Law, Edward Elgar Press, U of St. Thomas (Minnesota) Legal Studies Research Paper No. 17-04, Washington \& Lee Legal Studies Paper No. 2017-10, 2017), pp. 582-4. 
of CSR in the US, it can be seen that there is still no obligation binding on corporations because CSR is still voluntary and not legally binding.

The UK is another developed country and CSR in the UK has witnessed a remarkable increase in terms of implementation. When a review was undertaken in issuing a modern UK company law, it concentrated on the role of the company towards stakeholders, as company directors required their companies to consider, not only shareholder interests, but also the interests of stakeholders. ${ }^{49}$

Thus, in the modern Company Law Review in 2002, section 3.3 provided for the following:

the review considered to whom directors should owe duties... the basic goal for directors should be the success of the company in the collective best interests of shareholders, but that the directors should also recognize, as the circumstances require, the company's need to foster relationships with its employees, customers, and suppliers, its need to maintain its business reputation, and its need to consider the company's impact on the community and the working environment. ${ }^{50}$

As a result, the Companies Act 2006 in the UK clearly identified the company's directors as having an obligation to consider the benefits of the many internal and external organizations, including the community and the environment, that are at the heart of CSR. ${ }^{51}$ In contrast, it has been claimed that the essence of the UK Companies Act is the emphasis on shareholder supremacy which can be a major factor that hinders CSR activities in the UK. ${ }^{52}$ Nevertheless, although CSR in the UK is still not legally binding, and its implementation is on a voluntary basis

49 See S. Sheikh, Corporate Social Responsibility: Law and Practice, London: Cavendish, 1996, p. 153, mentioned in J. Lowry, A. Reisberg, Pettets's Company Law: Company Law $\mathcal{E}$ Corporate Finance, 4th ed., Pearson Education Limited, 2012, p. 68.

50 J. Solomon, A. Solomon, Corporate Governance and Accountability, John Wiley \& Sons Ltd, 2004, p. 188.

51 Section 172 of UK Companies Act 2006 reads as follow: b) the interests of the Company's employees, c) the need to foster the company's business relationships with suppliers, customers and others, d) the impact of the company operations on the community and the environment. Also see D. French, C. Ryan, S. Mayson, Mayson, French E Ryan on Company Law, Oxford University Press, 2016, pp. 28-29.

52 Villiers, supra note 3, p. 94. 
among business corporations, as they are compelled to issue frequent reports in regarding their CSR activities, ${ }^{53}$ it has been found that some UK corporations choose to apply responsible business practices voluntarily, which mainly include the following: ${ }^{54}$

- To treat employees fairly and with respect;

- To operate in an ethical way and with integrity;

- To respect basic human rights;

- To sustain the environment for future generations;

- To be a responsible neighbour in their communities.

In addition, Europe is still not convinced that it should support CSR as legally binding on business corporations, preferring instead that CSR is managed through voluntary regulations. ${ }^{55}$

Eventually, the voluntary application of CSR can be justified and effective in countries where corporate managers have aligned corporate interests with those of the community. Thus, it could be submitted that voluntary CSR could be appropriate in a jurisdiction, such as in the State of Kuwait, that imposes indirect legal obligations on business corporations, where corporations would be paying from their profits to multiple entities. ${ }^{56}$ Therefore, in that case, business corporations would fight against the application of mandatory CSR because they would not

53 A. Alotaibi, F. Edum-Fotwe, A. Price, "Critical Barriers to Social Responsibility Implementation within Mega-Construction Projects: The Case of the Kingdom of Saudi Arabia", Sustainability, 2019, Vol. 11 (6), p. 8, https://doi.org/10.3390/su11061755.

${ }^{54}$ Coyle, supra note 29, p. 240.

55 Villiers, supra note 3, p. 92.

${ }^{56}$ Law No. 19 of 2000 Concerning Supporting and Encouraging National Labour to Work in Non-Governmental Bodies (19/2000) Article 12, provided for: 'A tax of 2.5\% of the annual net profit is imposed on Kuwaiti companies listed on the Kuwait Stock Exchange'. Law No. 46 of 2006 Concerning Zakat and the Contribution of Public and Closed Joint Stock Companies in the State Budget (46/2006) Article 1: An annual percentage of $1 \%$ of the net profits of Kuwaiti closed public shareholding companies takes place. These companies, upon submitting their approval of the receivables, have attached their annual budgets according to this law to determine the amount that represents zakat on their funds from the amount collected, and they also have to direct the amount due It, or a part of it, to a public service. KFAS, a private non-profit organization, was established in 1976 by an Amiri Decree to develop the culture of science, technology and innovation for a sustainable Kuwait. KFAS's charter represents the commitment by local shareholding companies to contribute 1 percent of their annual net profits to fund the foundation. Published in Kuwait official Gazette Vol: 1114 year 23. 
be able to sustain the burden of so many deductions from the benefits owed to shareholders. Moreover, the voluntary application of CSR is preferred in a jurisdiction that enjoys a high level of corporate responsibility which is an example of the managers of such corporations considering the carrying out of their duty not to benefit the corporation only, but also the other members of the community are considered.

\section{MANDATORY CORPORATE SOCIAL ReSPONSIBILITY}

The concept of CSR revolves around, requiring corporations to add community support to their objectives. Corporations must consider their role of helping the community as a citizen, which entails the corporation becoming an active member of society and is being constrained from doing anything harmful to it. Some supporters of CSR allege that corporations must operate their businesses in a way that benefits not only their shareholders, but also other constituencies, such as employees, creditors, and the community. ${ }^{57}$ Thus, a business corporation has responsibilities, and the role of business corporation is to run businesses to generate profit for their investors, but a corporation's role and behaviour towards the community has to be legally regulated by the government. ${ }^{58}$

Therefore, it has been argued that the legal regulation of CSR might be necessary to ensure that business entities do not ignore their responsibilities since their businesses have significant effects on employment, health, and the environment. ${ }^{59}$ Thus, the Corporate law is a major player in the CSR field, ${ }^{60}$ and it should not only aim to enhance the progress of business corporations, but also concentrate on minimizing corporate

57 B. Tricker, Corporate Governance Principles, Policies and Practice, Oxford: University Oxford Press, 2009, p. 36.

${ }^{58}$ Ibid., p. 350. It has been argued that the Corporate Law can be seen as an obstacle to implement the CSR because it encourages the managers only to maximize the shareholders profits - see B. Richardson, B. Sjåfjell, „Capitalism, the Sustainability Crisis, and the Limitations of Current Business Governance", in B. Sjåfjell, B. Richardson (eds.), Company Law and Sustainability: Legal Barriers and Opportunities, Cambridge University Press, 2015, p. 1.

59 Ibid.

${ }^{60}$ French, Ryan, Mayson, supra note 51, p. 32. 
damage to society. ${ }^{61}$ For instance, it has been mentioned that Korean corporate law is based on shareholder supremacy in regard to exploring the objective of incorporating a company, However, such a principle should not allow corporations to ignore their responsibility to not to engage in wrongdoings towards society. ${ }^{62}$

It is a fact that the CSR concept is not supported consensually by everyone, and thus there are many opinions against it. As mentioned previously the non-existence of a unified definition of CSR is a major reason that these opponents are not motivated to regulate CSR within a binding legal framework. ${ }^{63}$

Accordingly, the role of corporate law is important in determining CSR regulations (at least the corporate law will ensure that the corporations' directors act ethically), ${ }^{64}$ even though many issues can be solved with different existing laws; for example, corporate responsibility to protect the environment is regulated by environment law, and corporate duties to employees are governed by labour law. In addition, it has been found that many laws intervene in framing CSR, such as corporate law, taxation law, deceptive advertising law, and consumer protection law. ${ }^{65}$ Thus, it could be submitted that such laws' interference in the corporation's matters may hinder the management from achieving their main goal which is the maximization of the shareholders wealth and also could affect the corporation's sustainable development.

Moreover, it has been found that in developed countries, nongovernmental entities have a major impact with regard to implementing CSR, whereas in other countries such as China, laws and regulations are used to develop CSR, ${ }^{66}$ for example the partnership law in China provides clearly that partnership firms and their partners must be in com-

61 You, supra note 2, p. 4.

${ }^{62}$ Ibid., p. 7.

63 Tricker, supra note 57, p. 27.

64 Zhao, supra note 11, p. 110.

${ }^{65}$ H. Ward, "Corporate Social Responsibility in Law and Policy", in Boeger, Murray, Villiers, supra note 3, p. 19.

${ }^{66}$ H. Virginia, "Beyond Regulation: A Comparative Look at State-Centric Corporate Social Responsibility and the Law in China," Vanderbilt Journal of Transnational Law, 2012, Vol. 46, pp. 375-442. 
pliance with social morals and business ethics and must be socially responsible. ${ }^{67}$

Actually, corporate law is the law that first ignited the flame of all these issues because it results from the decisions of corporate managers and boards of directors. Such decisions and responsibilities are regulated by corporate law, and it is the appropriate place to incorporate CSR regulations. ${ }^{68}$

For example, Article 41 of the Italian Constitution provides for CSR, as it requires that private corporations do not undertake any business activity that might cause harm to society, and the law might be the tool to decide the appropriate business activities to serve the community ${ }^{69}$ Moreover, the UK Companies act imposes a duty on companies whose shares are traded on the London Stock Exchange to provide information regarding some issues regarding social and community issues and company employees amongst other things. ${ }^{70}$

Many governments have implemented CSR through a number of legal instruments, Disclosure is one of these instruments, as many corporations are required to disclose how their operations affect society and the environment in the country where they operate. ${ }^{71}$

Thus, the aforementioned disclosure regulation can be seen as the indirectly mandated regulation of CSR. ${ }^{22}$ On the other hand, directly mandated and officially mentioned CSR regulation is rare, and China has claimed that it was the first country to make use of the expression "corporate social responsibility" in corporate law.

The Chinese corporate law of 2006 stipulates that "in the course of doing business, a company shall comply with the laws and administrative regulations, conform to social morality and business ethics, act in good faith, subject itself to the government and the public supervision, and undertake social responsibility." ${ }^{173}$ CSR is mentioned clearly in cor-

${ }^{67}$ Chinese Partnership Law (2007) Article 7.

${ }^{68}$ Gevurtz, supra note 43, pp. 39-51.

69 A. Melis, S. Carta, S, Del Rio, “CSR and Integrated Triple Bottom Line Reporting in Italy: Case Study Evidence," in Mallin, supra note 6, p. 9.

${ }^{70}$ UK Companies Law 2006 s 414 C (4).

${ }^{71}$ French, Ryan, Mayson, supra note 51, p. 32.

72 Zhao, supra note 11, p. 122.

${ }^{73}$ Chinese Company Law (2006), Article 5. 
porate law in China as discussed above, and there are two schools of thought regarding the mandatory application of CSR in China.

The first school alleges that since CSR has not been defined in law, CSR provisions are merely an ethical obligation, and the same laws do not provide for punishments for noncompliance. ${ }^{74}$ In addition, they claim that such provisions are not viable in the end. On the other side of the argument, the second school encourages the application of CSR provisions in Chinese company laws, and furthermore, they consider such provisions mandatory and legally binding. ${ }^{75}$

Professor Lin has conducted an empirical analysis of the application of CSR laws in China, and the study reveals that CSR laws in China are inoperable, as the findings claim that implementing CSR laws must be compatible with the country's characteristics, such as the legal environment and socio-political institutions. Moreover, the study found that if CSR is applied by law, there must be a judicial body that understands the context of the CSR concept to ensure appropriate application of the law. ${ }^{76}$

Similarly, Indonesia in 2007 amended its corporate law to include that "the company having its business activities in the field of and/or related to natural resources shall be obliged to perform its social and environmental responsibility."77

The Indian Companies Act 2013 went further and required directors "to act in good faith in order to promote the objects of the company for the benefit of its members as a whole, and the best interests of the company, its employees, the shareholders, the community and for the protection of the environment". In addition, this act provided that there must be a CSR committee at board level and that $2 \%$ of the average net profit in the prior three years must be spent on CSR activities. ${ }^{78}$

Furthermore, the European Union has taken intermediate position since it has issued a CSR directive which requires the corporation to dis-

74 Zhao, supra note 11, p. 121.

${ }^{75}$ L. Lin, "Mandatory corporate social responsibility? Legislative innovation and judicial application in China", The American Journal of Comparative Law, 2020, Vol. 68(3), pp. 576-615.

${ }^{76}$ Ibid.

77 Indonesian Law No. 40 of 2007 on Limited Liability Companies, Article 74.

78 Indian Companies Act (2013), S. 135. 
close non-financial information regarding CSR activities, such directive is implemented based on the Comply or Explain pattern. ${ }^{79}$

Accordingly, the recognition of CSR laws should not ignore the reality that CSR is still a vague concept; therefore, the application of CSR laws must be examined to ensure that the legal instruments for applying CSR do not hinder other corporate objectives since CSR law in practice has not yet been thoroughly examined. ${ }^{80}$ It is noteworthy here that no legal system of any country around the world can claim that its provisions are effective and appropriate for all countries. ${ }^{81}$

It has been argued that the law, in essence, intends to hold persons accountable for implementing the legal regulations as provided, but that business firms should have corporate consciences like the consciences of individuals and be committed to operating their businesses compatibly with the laws. Thus, it can be argued that CSR laws should target the regulation of self-regulation inside business firms. In addition, with regard to applying laws to make corporations accountable for CSR, there must be safeguards. First, CSR law should clearly indicate the aims and goals that corporations should be responsible for. Second, responsibility must be within the corporation (institutionalized) and its practice and structure. Third, the corporation must not act only to be socially responsible, but should also pursue its original objectives, such as producing goods or providing suitable services.

However, in the mandatory CSR system, corporations will not compete to attract customers through more spending on CSR activities because they will all pay the same percentage towards CSR in the end. Moreover, when CSR is implemented based on mandatory rules, the

${ }^{79}$ EU Directive 2014/95/EU. Also see S. Alexander, "Soft Law Requirements With Hard Law Effects? The Influence of CSR on Corporate Law form a German Perspective", in U. Plessis, Varottil, J. Veldman (eds.), Globalisation of Corporate Social Responsibility and its Impact on Corporate Governance, Springer International Publishing AG, 2018, p. 18. Also see C. Wagner, "Evolving Norms of Corporate Social Responsibility: Lessons Learned from the European Union Directive on Non-Financial Reporting", Transactions. The Tennessee Journal of Business Law, 2018, Vol. 19, pp. 625-626.

80 Ibid.

${ }^{81}$ J. Javillier, "Corporate Social Responsibility and Law: Synergies Are Needed for Sustainable Development", in Governance, international Law and Corporate Social Responsibility, Geneva: International Labour Organization, International Institute for Labour Studies, Research Series, 2008, Vol. 116, pp. 37-62. 
cost of such implementation will be high because the corporation and the government will need to employ more staff to supervise and monitor the adequate application of CSR. ${ }^{82}$

Furthermore, many corporations have recruited CSR managers who are responsible only for CSR. In addition, CSR consultancies have contracted with corporations to write CSR reports and review and verify CSR codes or regulations and also to train employees on how to adequately enforce such codes. ${ }^{83}$

There is an allegation that intervening in corporations' policies and thereby forcing them to consider the benefit of external organizations such as the community and the environment is not democratic. ${ }^{84}$ Further, when arguing against mandatory CSR, one can claim that it could result in detrimental situations, such as what is known as triple taxation. In that case, under the corporate tax system, the corporation's profit is taxed in addition to the dividend tax, and at the end, the corporation will also be forced to pay for CSR.

Consequently, many challenges might confront the implementation of CSR law, one of the most important being how the judicial system, namely, the judges in the courts, will not understand the difficult terminology and ideas that are included in CSR law when it is presented before them, when a dispute must be solved or when interpretation is needed. ${ }^{85}$ In addition, the way of implementing the CSR laws and regulations is a major factor as it has been found that a jurisdiction that has a strong legal system will ensure the proper implementation of CSR laws and regulation more than a jurisdiction that suffers from a weak legal system. ${ }^{86}$

Moreover, it has been said that defining CSR is not an easy task since it is affected by political issues. ${ }^{87}$ Thus, a major issue should always be kept in mind when there is an intention to legislate CSR law, i.e. the po-

82 Japhet, Tawiah, Benjamin, supra note 1, p. 5-6.

${ }^{83}$ McBarnet, supra note 36, p. 4.

${ }^{84}$ Backer, supra note 40, p. 302.

${ }^{85}$ Ibid., p. 7.

${ }^{86}$ W. Lee, S. Choi, "Internal and External Corporate Social Responsibility Activities and Firm Value: Evidence from the Shared Growth in the Supply Chain", Borsa Istanbul Review, 2021, p. 3, available online at: www.Sciencedirect.com [last accessed 8.6.2021].

87 Javillier, supra note 81. 
litical situation. For instance, in regard to detrimental interference from the politicians, in Kuwait, the political environment (the members of parliament and the official cabinet) could be affected by business factors on many occasions; in other words, the legislators in Kuwait on many occasions legislate or amend legislation aimed at protecting certain business parties.

For example, in 2012, the New Companies Law Decree No. 25/2012 was issued. It provided for mandatory accumulative voting for electing the boards of publicly held corporations, which is considered a very important issue in protecting minority shareholders, but a few months later, this provision had been amended by Law No. 97/2013 to make accumulative voting in board elections optional. ${ }^{88}$ Such interference exemplifies that the policymakers might be affected by business members when they intend to issue legislation which affected their benefits.

Furthermore, it is noteworthy that under Islamic law, duties can be a major player in applying CSR since one of those duties is the obligatory tax (Zakat). ${ }^{89}$ In this vein, CSR in the GCC countries has been described as follows:

Islamic religion in the GCC countries views social responsibility as an obligation of business activity mainly through the Zakat tax. However, the Zakat tax was practised way before the CSR concept came to light and is considered as only one of the secondary pillars of CSR practices which is philanthropic. Social responsibility is present in the GCC in Islamic financial institutions as well..$^{90}$

For example, Saudi Arabia imposes a $2.5 \%$ tax on corporate headquarters, and the government must spend it on socially beneficial activities, but it has been argued that the lack of direct legislation related to CSR has resulted in a weak infrastructure for the sound implementation

${ }^{88}$ See Law Decree No.25/2012 Article 240 and its amendment by Law No. 97/2013 in Kuwait.

${ }^{89}$ Jamali and Safadi, supra note 9, p. 132. For more elaboration of the Zakat see: I. Sidik, R. Reskino, "Zakat and Islamic Corporate Social Responsibility: Do These Effect The Performance Of Sharia Banks?", Journal of Economics and Business, May-August 2016, Vol. 1, No. 2, pp. 161-184.

${ }^{90}$ Ibid., p. 133. 
of CSR, and thus, the limited availability of applicable laws can be seen as a major challenge to applying CSR best practices. ${ }^{91}$

Likewise, Qatar has been criticized for not applying legal regulations to the private sector regarding their involvement in helping society. ${ }^{92}$ Kuwait, from the same region, has a weak legal infrastructure for CSR, as corporations in Kuwait are not subject to taxes, However, they contribute their profits to society in a number of ways in Kuwait, such as the Zakat Law and the Kuwait Foundation for Advanced Sciences. ${ }^{93}$ Because, such indirect obligations may result in an adverse effect on the corporations and they will be subject to too many deductions from their profits, it could be submitted that instituting a suitable legal framework would be a major development for CSR practices in Kuwait and other countries in the region.

Ultimately, it has been emphasized by the extremist supporters of CSR that corporations not only should be legally obligated to obey regulations enacted locally, but also the legislation should be expanded so that corporations are legally obligated to obey international directives related to CSR. ${ }^{94}$

Therefore, it could be submitted that if CSR is implemented as a hard law it should not prevent or discourage the corporation from achieving its main goals and responsibilities, ${ }^{95}$ as it has been claimed

${ }^{91}$ Ibid., p. 129.

${ }_{92}$ Ibid., p. 131.

${ }^{93}$ Law No. 19 of 2000 Concerning Supporting and Encouraging National Labour to Work in Non-Governmental Bodies (19/2000) Article 12, provided for: 'A tax of 2.5\% of the annual net profit is imposed on Kuwaiti companies listed on the Kuwait Stock Exchange'. Law No. 46 of 2006 Concerning Zakat and the Contribution of Public and Closed Joint Stock Companies in the State Budget (46/2006) Article 1: An annual percentage of $1 \%$ of the net profits of Kuwaiti closed public shareholding companies takes place. These companies, upon submitting their approval of the receivables, have attached their annual budgets according to this law to determine the amount that represents zakat on their funds from the amount collected, and they also have to direct the amount due It, or a part of it, to a public service. KFAS, a private non-profit organization, was established in 1976 by an Amiri Decree to develop the culture of science, technology and innovation for a sustainable Kuwait. KFAS's charter represents the commitment by local shareholding companies to contribute 1 percent of their annual net profits to fund the foundation. Published in Kuwait official Gazette Vol: 1114 year 23.

${ }^{94}$ Backer, supra note 40, p. 297.

${ }^{95}$ Ibid. 
that CSR laws will prevent corporations from achieving their traditional and main objective, which is maximizing shareholder wealth. Furthermore, the legislation of CSR laws will not ensure that they are adequately implemented. ${ }^{96}$

Accordingly, CSR implementation whether mandatory or voluntary should be decided based on the conditions of the country in question, taking into account that both mandatory or voluntary CSR have their advantages and disadvantages as discussed in this paper. But, we suggest that CSR should be implemented through a voluntary system since it touches upon other people's benefits, and they should decide the way they want to spend their wealth, but the policymakers should encourage the corporations to contribute to the community needs by offering some benefits to such corporations, such as reducing the tax rate. In this case the corporations will be encouraged to work more and positive returns to the community will ensue.

Nonetheless, if CSR is mandatory, then the legal profession will be engaged with it, as then the law firms will be obliged to advise their client with issues related to CSR. Sune Skadegaard also expressly delivers the following passage in this regard: "It has nothing to do with law, it is not a concern to us and it is interesting, but we do not have time to develop a new field." 97

\section{CONCLUSIONS}

This paper aims to explore a better legal system to implement corporate social responsibility around the world. It has transpired that CSR has no unified definition around the world, and the existing definitions differ with the views of the definers. How best to implement CSR has been debated, as in some countries CSR is mandatory, which means that CSR is applied to corporations by laws and regulations.

${ }^{66}$ Lin, supra note 75, pp. 600-604.

97 S. Thorsen, "Lawyers - Facing Corporate Social Responsibilities" - speech Delivered at a Seminar on "Governance, International Law and Corporate Social Responsibility" (Geneva: ILO Headquarter, 2006), mentioned in Governance and International Law \& Corporate Social Responsibility, International Institute for Labour Studies, Research Series No. 116 (Geneva: International Law \& Corporate Social Responsibility, 2008), p. 122. 
Binding CSR has its advantages and disadvantages; for example, binding CSR may lead to less competition among corporations, as they do not need to compete to enhance their image by serving the community in front of their citizens because binding CSR mandates their equal payments and thus their equal image in the community. Moreover, it has been found that binding CSR may result in multiple payments to the government and the community, which ultimately leads to the exhaustion of corporate budgets.

Furthermore, binding CSR could be seen as important to benefit the community since corporations are gaining profits and must benefit organizations outside of corporations, such as society. Thus, a number of countries such as China have provided for corporate social responsibility in their laws and to achieve the best result from binding CSR, it must not hinder business corporations' goals, which generate profits and maximize the wealth of shareholders.

On the other hand, corporate social responsibility might be implemented on a voluntary basis, as corporations may or may not participate in their communities. Nonbinding CSR gives corporations the liberty to work without constraints, which means that corporations can benefit from most of their profits, whether to maximize their business or to distribute it amongst shareholders. Nonetheless, voluntary CSR gives corporate managers the discretion to participate in the community, but such rights might not be used by managers.

Finally, it could be submitted that there is no one model for corporate social responsibility around the world. In addition, weighing which system is better between the mandatory and voluntary systems of CSR depends on each country's legal system.

Moreover, it has been suggested that CSR regulations vary from one country's legal system to another since such regulations must be compatible with multiple factors, such as the social, economic, and legal environments in each country. Accordingly, when drafting CSR regulations or laws, policymakers should consider many aspects, such as the social and economic characteristics of the country and should not simply adopt another country's model of CSR. However, we suggest that the nature of the goal of corporate social responsibility recommends that voluntary implementation of CSR could be preferred provided that it was accompanied with governmental privileges that encourage such corporations to work more and benefit the community more at the same time. 
